\title{
Can Society Nurture Humanistic Marketing?
}

\author{
Aliakbar Jafari \\ University of Strathclyde, Glasgow - UK
}

In: Richard Varey and Michael Prison (Eds.) Humanistic Marketing. London: Palgrave Macmillan. pp. 113-125.

\begin{abstract}
For more than four decades, academic debates on the morality of marketing have focused mainly on the advantages and disadvantages of marketing as an institution. This essay questions the usefulness of such debates to addressing many challenges of life in contemporary society and argues that engagement in such discussions will only entrap us in vicious circles of argumentation. The author calls for collective social responsibility and argues that humanistic marketing can only be realised in a humanistic society.
\end{abstract}

\section{"Every man is guilty of all the good he did not do." (Voltaire)}

We are all guilty. For unethical business practices, increasing environmental crises, overconsumption, market misbehaviours, social injustice, falling rate of satisfaction with life, institutionalisation of fraud, declining morality in society, and many other imperfections, we are all guilty. We are guilty because we have developed too much hope and faith in markets - 'the idols of our own creation' (Wallis, 2010) - and market rules. Markets, which once upon a time cultivated the seeds of hope, prosperity, happiness, peace, and harmony in human society, have now become the breeding grounds for despairs, difficulties, agonies, anxieties, and conflicts. Markets, which used to bring people together in society, have now become battlefields where people stand in opposition and anxiously blame one another for the imperfections of their habitat, 'the market'. In this battleground, angry voices are heard from all corners. Everybody in the field is simultaneously a plaintiff, a defendant, and a judge.

In the battlefield of the market, we are all anxious. As consumers, we are becoming increasingly sceptical of suppliers' true value propositions (Tan, 2002). We are suspicious of their honesty. We are fed up with the copious volume of unsolicited advertisements targeting us in different forms (e.g., TV screens, electronic mails, text messages, telephone calls, direct mails and flyers) (Shankar and Malthouse, 2007). We are agitated by the way governments measure their overall performance based 
on the size of our pockets and not the width of our smiles. Particularly in the West, not a single day goes by without governments and corporations measuring their economic performance based on consumers' expenditure. As consumers, we are also annoyed by one another, our fellow habitants. We are tired of keeping up with the Joneses. We are fed up with one another's misbehaviours (e.g., bad consumption of things and consumption of bad things) in the market. We are tired of one another's increasingly calculative behaviours. Especially at the time of economic downturn, shrinking of our pockets is making us more calculative and less generous to one another. We need a break from the market.

Businesses are in no better condition. Most businesses are getting disappointed in their customers' disloyalty. Return on investment is a major concern which haunts their day to day activities from dawn till dusk (Oliver, 1999). Nowadays, relationship marketing schemes are often run based not on the traditional concepts of voluntary support, trust and commitment, but on coercive financial motivations. Most businesses do not voluntarily take initiatives to enhance the value and quality of their offerings; they often do so because they are forced to, by fierce competition, rising consumer complaints, or compulsory regulations (Morgan and Hunt, 1994). Businesses also live with the fear of being sued by their customers, business partners, or employees for the slightest harms they may cause to them. They also suffer from misbehaviours of consumers (Bitner et al., 1994; Harris and Dumas, 2009). Some consumers justify their theft (in any form and quantity) in the name of poetic justice. Others willingly abuse the good will (and sensible business strategy) that underpins refund policies and - at the most extreme - sometimes consumer antipathy towards corporations results in abusive language and aggressive physical behaviours towards employees (see Daunt and Harris, 2011). In this battlefield, businesses do not get a break either.

This essay is a flag of truce. It is a call for ceasefire in this battlefield. This essay invites all the plaintiffs, defendants, and judges to drop their angry voices, take a deep breath, and sit down for a chat around the table, but not in the battlefield. The battlefield is not the right place for negotiation. It stimulates antagonism. The battlefield brings temptations of winning one's own mission and of defeating the opponents. Negotiation needs serenity. This essay invites all the militants to leave the battlefield of the market and establish a dialogue around the table of conscience somewhere else, in the heart of society. In society civilians live, not militants. Civilians are citizens, not opponents. Citizens live together. Citizens are neighbours, friends, relatives, and next of kin. In society, "human beings are members of a whole, in creation of one essence and soul. If one member is afflicted with pain, other members uneasy will remain."1

This essay is a call for Collective Social Responsibility (CSR). The core of my argument is that humanistic marketing can only be realised in a humanistic society. For the purpose of this discussion, I use the term 'humanistic' precisely to denote the belief in the welfare of society at large based on self-examination, conscience,

\footnotetext{
${ }^{1}$ Quotation from Sa'di, the Iranian poet (1185-1283/1291)
} 
honesty, respect, passion, ethics, responsibility and action. As I have just said, and I repeat myself, humanistic marketing can only flourish in a humanistic society. Therefore, before embarking on a humanistic charter for marketing, we need to meticulously and conscientiously examine whether or not our society provides the breeding grounds for the 'revival' ${ }^{2}$ of such a humanistic enterprise.

Allow me to continue this dialogue with a generally agreed thesis that marketing, as an institution, does not operate in a vacuum (Peñaloza and Venkatesh, 2006; Tadajewski, 2010). There are many institutions that influence the nature, performance, and direction of marketing. Marketing executives within organisations, for example, often work towards serving their businesses' overall economic objectives (Friedman, 1970). Hence, the philosophy of marketing (which ideally should offer value for society at large ${ }^{3}$ ) is likely to be overshadowed by the sole philosophy of making profit (Bell and Emory, 1971). Similarly, highly institutionalised marketing academics and educators barely transgress the boundaries of their market-centred logosphere ${ }^{4}$. Typically, instead of studying marketing in society, they analyse society within the limited boundaries of the market logic (Venkatesh et al., 2006). As a result, marketing remains largely at a 'micro level' (FIrat and Dholakia, 1997; Varey, 2010). As active agents, customers and consumers are also capable of influencing organisations' marketing practices and business patterns (Wright et al. 2006) through, for instance, spreading positive or negative word of mouth, feeding and pursuing their complaints, and increasing or decreasing their level of financial transaction with organisations. Through policy change and enforcing regulations, governments also influence the content as well as structure of markets and marketing practices (Menon and Menon, 1997; Jafari and Goulding, 2012). Therefore, marketing is not, and should not be viewed as, an independent omnipotent entity. Marketing, as an institution and social construction, is the common product of complex and multiple interactions amongst a large number of other institutions. Therefore, too much reliance on marketing is a grave mistake. Marketing alone has neither the power nor the means to affect society.

\footnotetext{
${ }^{2}$ I use the term 'revival' deliberately because contemporary humanistic discussions (including, for example, the broad arena of Modern Humanism) are historically rooted in mankind's yearning for morality, ethics, justice, and collective welfare in society. In the general context of business and management studies, the history of ethics and morality dates back to antiquity (both ancient and late).

${ }^{3}$ This is the core of American Marketing Association's 2007 definition of marketing which is widely accepted by proponents of societal marketing. This is a controversial definition as some (e.g., advocates of 'business for business sake') may not agree with it. Here I am not, by any means, rejecting the idea of making profit; on the contrary, I am suggesting that making profit should not happen at the expense of societal values, in which case businesses are doomed to face the consequences of their opportunistic and unethical activities.
}

4 By 'logosphere' I mean the linguistic realm (e.g.,terminology, definitions, meanings, and interpretations) which reflects the underlying values and ideology of business schools and schools of management. 
Let us be clear about the key message of this book, part of which is the present essay. Calling for a humanistic marketing has one alarming implication: the way we collectively (as marketing practitioners, academics, consumers, and other stakeholders) have been theorising, practising, and interacting with markets and marketing so far has not worked for the common good. If it had worked for the common good, now we would not witness a growth in cynicism and scepticism towards the effectiveness of markets (Wallis, 2010) and marketing (Chylinski and Chu, 2010). In fact, in many ways, we have failed to make effective use of markets and marketing for the betterment of human life in general. And for this failure we are all guilty.

In the remainder of this essay, I will discuss why we are guilty. In order to develop this discussion, I proceed with an overview of contemporary debates on the morality of marketing with specific reference to consumption. I will particularly argue how some of the key concepts in this stream of debate are flawed. My conclusion is that establishing a humanistic marketing necessitates collective social responsibility in all areas of social life, including our varying interactions with both markets and marketing.

\section{The morality of marketing}

At least for the past four decades, we have witnessed a plethora of contested debates about the morality of marketing. On the one hand, marketing has been blamed for using manipulative promotional techniques, exploiting societies' multiple resources (e.g., economic, social, cultural), accelerating consumerism, cultivating artificial values, and so forth; and on the other hand, it has been praised for serving society in different ways such as enhancing quality of life, serving consumers' varying needs, democratisation of society, educating people, driving innovation, circulating capital and the like. These perspectives deserve to be separately analysed in further depth; yet, given the space constraints of this account, in the following lines, I will stick only to a brief review of the topic (morality of marketing) and its relation to consumption.

\section{Perspective 1: marketing blamed}

From this perspective, marketing is seen as a tool that profit-seeking organisations use to accelerate consumption in society. Critics (e.g., Packard, 1957; Day and Aaker, 1997; Lambin, 1997) often refer to consumerism and blame marketing for employing manipulative techniques (e.g., advertising) and practices (e.g., promotions and discounts) that tempt consumers to buy and consume more. For instance, Day and Aaker (1997, p. 44) echo Packard's (1957) criticism of marketing "strategies for persuading customers to quickly expand their needs and wants". Similarly, Lambin (1997) uses the term 'wild marketing' to denote the type of marketing which is "characterised by an emphasis on selling at the expense of meeting consumers' needs and expectations" (Yani-de-Soriano and Slater, 2009, p. 454). According to Lambin, this type of marketing exploits people's anxieties, insecurities, and sufferings, driving them towards overconsumption through impulsive and compulsive behaviours. Such conceptions of marketing argue that "consumerism not only does 
not promote consumer wellbeing, but has damaging consequences for consumers and society" (Yani-de-Soriano and Slater, 2009, p. 454). Such consequences are as diverse as indulgence in false values and identities (Bauman, 2000), status competition (Schor, 1999), financial debt (Setterfield, 2005; Charpe et al., 2009), illness (Faber et al., 1995; Szmigin et al., 2011), and anxiety (Bauman, 2000). Individual consequences aside, consumerism also threatens the collective and longterm survival of human beings by using natural resources faster than they can be renewed or replaced (Brown and Cameron, 2000). For instance, through shortening product lifecycle and cultivating fads in fast moving consumer goods, products are not fully used by consumers. There is inherent waste. Even the most sophisticated advancements of recycling or remanufacturing cannot catch up with the rapid expansion of environmental destruction. Based on such premises, and from a societal perspective (Kotler, 1972; Takas, 1974; Abratt and Sacks, 1988; Prothero, 1990), marketing is deemed to be responsible before society. This perspective rejects Friedman's (1970) thesis of 'business for business' sake' and considers businesses as social enterprises which should be committed to the long-term benefits of society.

\section{Perspective 2: marketing defended}

In this second perspective, it is believed that marketing serves human society by providing individuals with necessary means of organising their lives. Voices in this stream are diverse as they come from different theoretical camps. From a moral and political perspective, Gaski (1985) and Crane and Desmond (2002) question the foundations of societal marketing and argue that the concept of social responsibility creates many complications. In their view, it would be morally and politically dangerous to put marketing managers in charge of safeguarding society's wellbeing: societal marketing "constructs a role of the marketing manager to decide on and act in defence of the public interest, despite neither being elected to do so, nor necessarily having any expertise in doing so" (Crane and Desmond, 2002, p. 558). The authors suggest that only governments should be responsible for making decisions on people's wellbeing because marketing managers cannot decide what is good for society. The rationale is that in a democratic context, marketing managers should fulfil their task by supplying society with a diversity of products and services, and consumers themselves are capable of deciding what is good for them.

From a social values perspective, O'Shaughnessy and O'Shaughnessy (2002) also argue that those who blame marketing for accelerating consumerism (e.g., hedonistic behaviours and overconsumption) and changing society's values fail to understand that human society has always been dynamic and people's values have always changed throughout history. In this regard, marketing only changes people's perspectives towards what is of value: "marketing seldom tries to change values altogether, though it may seek to change value judgements through changing perspectives as to what is in line with values" (O'Shaughnessy and O'Shaughnessy, 2003 , p. 545). These authors further argue that through marketing-generated consumption culture, consumers get to practise their free will and enjoy what makes them who they want to be. Also, from an international perspective, Czinkota and Ronkainen (2003, p.14) argue that marketing immensely benefits consumers in all 
parts of the world: "consumers are the greatest beneficiaries of all. They are offered an unprecedented degree of product availability and choice....the prices of these products are usually low and offer a better quality and quantity of life to a broad spectrum of individuals."

\section{Catch-22}

Despite their potential in generating debate in public domains (e.g., media and public policy), educational environments, business forums, and academic outlets (e.g., conferences and journal publications), the above discussions are no longer truly progressive. Engagement in such discussions will only entrap us in vicious circles of argumentation. Given the depth and breadth, and also the urgency of dealing with, the problems (mentioned in the opening paragraph) we face in contemporary society, these discussions are less likely to help us arrive at a consensus about what the key cause of these problems is. These discussions are more divisive than unifying.

The dilemma embedded in the above discussions about the advantages and disadvantages of marketing is the result of asking the wrong questions: 'is marketing good or bad?' and if bad, 'who is guilty?' I have already answered the second question in the beginning of this essay and will return to it again in the upcoming paragraphs. Regarding the first question, it is misleading. This question distracts us from diagnosing the problem and will only engage us in sophistry and in endless discussions on who has caused the problem. Therefore, what I propose here is that we need to raise the right question: 'why have we ended up in where we are?' Some may still ask: 'but where are we?' Those who are not fully aware of 'where we are' need to seriously and conscientiously contemplate our everyday life conditions in the battlefield I elaborated in the beginning of this essay.

As I have discussed so far, the fundamental question of 'why have we ended in where we are?' has been overlooked. This is the very right question we need to ask ourselves. In the battlefield of the market, marketing is only one of many other institutions that shape our everyday life conditions. Marketing has not come from Mars. Every tree is known by its fruit; and marketing is the very fruit of our own society. Whether virtuous or vile, marketing only mirrors our own image. Marketing is the legitimate child of our own aspirations, ideas, ideals, and actions. As long as we measure our standards of living, quality of life, happiness, and wellbeing based on our material possessions and market resources, marketing shall continue to be a fundamental source of facilitating such utopian aspirations. The root cause of our imperfections definitely lies somewhere else.

Now, let us go back to my initial discussion on the topic of morality. Allow me to present my critique of the debate on morality of marketing with the help of an example. Amongst many possible examples, I deliberately use the case of smoking, an addictive behaviour, because it best uncovers some of the most fundamental contradictions in discussions on morality. 


\section{'Smoking Kills'}

Smoking is a dangerous form of consumption which has many negative consequences; simply said, it threatens wellbeing (at least physiologically and financially). In line with the above arguments, first let us set the scenario and then, in the light of the two perspectives, discuss who is responsible for the negative consequences of smoking. As Palazzo and Richter (2005) and Schwartz and Carroll (2003) elaborate, there is an inherent contradiction in the corporate social responsibility of tobacco companies. These companies produce and market dangerous products. At the same time, they claim that by warning consumers of the risks of smoking they accomplish their responsibility by telling smokers that 'smoking kills'. In this situation, where dangerous products are produced, one key question arises: can we speak of ethical business in the case of tobacco companies? The existence of the tobacco business harms health. In this case, who is guilty for the negative consequences of the dangerous product? Tobacco companies for making such products available? Consumers for consuming these products? Or governments for allowing these companies to operate?

Based on the first perspective, marketing could be blameworthy simply because 'smoking kills' and tobacco companies knowingly continue to produce and market their products. Based on the second perspective, however, there are many reasons for exempting marketing from guilt: firstly, governments set (at least in most developed countries) a series of regulations that restrict the production (quality control), marketing (advertising and distribution), and consumption (minimum age criterion and bans on smoking in public places) of tobacco products. And marketing, in its turn, abides by such regulations. For instance, tobacco companies warn consumers of the dangers of smoking. Secondly, marketing can be used in counteraction (social marketing and demarketing) by NGOs and public health organisations to de-market smoking. Thirdly, according to the democratic law of free market, a large number of smokers should have the right to access the product they want. Fourthly, smokers are aware of the fact that 'smoking kills'; therefore, they do not need guardians to tell them what is good or bad for them.

There are a series of problems here. Based on the logic of perspective 1, consumers are not held responsible for the harm they cause to themselves and others. In a one-way tradition, perspective 1's logic ignores the agency of consumers and their participation in the process of self-destruction and wasting communal resources such as public health services and funds that can be used for promoting positive behaviours (e.g., sports) rather than preventing negative behaviours (e.g., smoking). This perspective essentially views marketing as the key cause of creating desires in consumers and does not acknowledge the fact that marketing may simply respond to the untameable 'fire of desire' (Belk et al., 2003) inherently nested in consumers' nature. People may adopt smoking not as a result of being exposed to the classic persuasive Marlboro Man advertisement; they simply may start because they are born into families where parents smoke.

On the other hand, perspective 2 oversimplifies the scenario. For instance, if we apply O'Shaughnessy and O'Shaughnessy's (2003) thesis of 'practising one's 
free will through consumption' to this context, smokers chose to smoke because that makes them who they want to be. But the problem exactly is the way of being who we want to be. If our being who we want to be does not impose any harm on others, I do not see any reason why one should be deprived of achieving that mode of being. But in the case of smoking, smokers' achieve their sense of being at the expense of others' costs. For instance, they expose others to passive smoking. They spend the money they should spend for the welfare of their family (or themselves) on smoking. As a result of developing health problems (because of smoking), they are more likely to utilise the communal national health services that are sponsored by all taxpayers.

Crane and Desmond's (2002) overreliance on democratic states (as the guardians of citizens) is also problematic. Firstly, these authors oversimplify democracy. In a democratic society, states are in charge of setting regulations and law and not moral codes for citizens. Regulations and moral obligations are two different things. For instance, simply because one is entitled to use free national health services does not justify the fact that one should use this resource. Nothing is illegal here but something is definitely immoral. Secondly, the authors' solution is narrowed down to democratic societies. What about those societies which do not have democracies and sophisticated regulatory systems? Who should be responsible for outlining their morality? The democracies that they do not have? Can it then be concluded that because they do not have democracies, they have no or little morality in society? Czinkota and Ronkainen's (2003) thesis is also not able to answer these questions. Many developing countries do not yet have sophisticated institutions (e.g., NGOs and legislations) to counteract the negative consequences of consumption.

These questions are difficult, if not impossible, to answer. If we extend this debate to other consumption situations in the everyday reality of our lives (e.g., overconsumption, consumption of alcohol, gambling, computer games, using 4X4 vehicles, impulsive and compulsive consumption, unhealthy dietary habits) we will encounter even more frustrating questions, ambiguities, and contradictions. Involvement in these questions will only make us raise our voice and blame one another for all the problems we face. That is why I called for a collective departure from the market in order to resolve our conflicts.

\section{Departure}

In this essay 1 have endeavoured to invite all members of society to think about our own actions. Our problems are abundant; so are the causes of these problems. And to resolve these problems, we all have a role to play. In Aristotle's words, "one swallow does not make a spring". We need to collectively take responsibility for the betterment of life on earth. So far, we have done different things and achieved one thing in common: we are facing more and more problems. Now, it is time we all did one thing in common to achieve different things (happiness, health, peace, harmony, etc.). That one same thing we should all do is to let our instinctive human conscience determine our thoughts, words, and deeds. We need to think in and for society. 
By departure, I do not mean total abandonment of the market; the market is part of our lives. What I suggest is that we need to remember that the market should serve us not rule us. Extending our selves through consumption and material possessions (Belk, 1988) has only multiplied our problems. It is time we seriously considered contracting our selves and thereby see the impacts of our multiple interactions with markets in our everyday life situations in society.

The problems I listed in the opening paragraph of this essay are certainly more tangible in economically developed (Western) contexts. That is why, to date, many debates on the morality of marketing have focused on such societies. But these problems are also becoming serious challenges for people in developing countries. The discussions of morality in developed countries often reach a dead-end because the ideology of democracy acts as a double-edged sword. Democracy creates a carte blanche where everybody can claim to be entitled to do whatever they want. Decisions on morality are therefore left to the discretion of governments, and all members of society become conditioned to live according to the rules set by their guardians. In other words, in the long term, morality is replaced by rules. Rules should accompany and be founded on, and not replace, morality. Rules can always be counteracted by other rules. But conscience-driven morality is enduring. Human societies all around the world, therefore, need to refer to their own conscience and take responsibility and action for the betterment of their lives. Too much hope in markets, market rules, and marketing will only create disillusions. Humanistic marketing can only come to existence and fructify in a society that craves for such a social enterprise.

\section{References}

Abela, A. (2006) Marketing and consumerism: A response to O'Shaughnessy and O'Shaughnessy". European Journal of Marketing, 40(1/2), pp. 5-16.

Abratt, R. and Sacks, D. (1988) The marketing challenge: Towards being profitable and socially responsible. Journal of Business Ethics, 7(7), pp. 497-507.

Bauman, Z. (2000) Liquid modernity. Cambridge: Polity.

Belk, R.W. (1998) Possessions and the Extended Self. Journal of Consumer Research, 15 (2), pp. 139-68.

Belk, R.W., Ger, G. and Askegaard, S. (2003) The Fire of Desire: A Multi-Site Inquiry into Consumer Passion. Journal of Consumer Research, 30 (3), pp. 326-52.

Bell M.L. and Emory, C.W. (1971) The Faltering Marketing Concept. Journal of Marketing, 35(4), pp. 37-42.

Bitner, M.J., Booms, B.H., and Mohr, L.A. (1994) Critical Service Encounters: The Employee's Viewpoint. Journal of Marketing, 58(4), pp. 95-106.

Brown, P.M. and Cameron, L.D. (2000) What can be done to reduce overconsumption? Ecological Economics, 32(1), pp. 27-41.

Chandon, P. and Wansink, B. (2007) The biasing health halos of fast food restaurant health claims: Lower calorie estimates and higher side-dish consumption intentions. Journal of Consumer Research, 34(3), pp. 301-304. 
Charpe, M., Flaschel, P., Proano, C. and Semmler, W. (2009) Overconsumption, credit rationing and bailout monetary policy: A Minskyan perspective. Intervention: European Journal of Economics and Economic Policies, 6(2), pp. 247-270.

Chylinski, M. and Chu, A. (2010) Consumer cynicism: antecedents and consequences. European Journal of Marketing, 44 (6), pp. 796-837.

Czinkota, M.R. and Ronkainen, I.A. (2003) An international marketing manifesto. Journal of International Marketing, 11(1), 13-27.

Daunt, K. and Harris, L. (2011). Exploring the forms of dysfunctional customer behaviour: A study of differences in servicescape and customer disaffection with service. Journal of Marketing Management, 28(1\&2), pp. 129-153.

Day, G.S. and Aaker, D.A. (1997) A guide to consumerism: what is it, where did it come from, and where is it going? Marketing Management, 6(1), pp. 44-48.

Dowling, Grahame R. and Mark Uncles (1997) Do Customer Loyalty Programs Really Work? Sloan Management Review, 38 (Summer), pp. 71-82.

Faber, R.J., Christenson, G.A., Zwaan, M.D. \& Mitchell, J. (1995) Two forms of compulsive consumption: Comorbidity of compulsive buying and binge eating. Journal of Consumer Research, 22, pp. 296-304.

Fırat, A.F. and Dholakia, N. (1997) Consumption patterns and macromarketing: A radical perspective. European Journal of Marketing, 11(4), pp. 291-298.

Gaski, J.F. (1985) Dangerous territory: The societal marketing concept revisited. Business Horizons, 28 (4), pp. 42-47.

Grant, J. (2000) The New Marketing Manifesto: The 12 Rules for Building Successful Brands in the 21st Century, UK: Thomson.

Harris, L.C. and Dumas, A. (2009) Online consumer misbehaviour: an application of neutralization theory. Marketing Theory, 9 (4), pp. 379-402.

Jafari, A. and Goulding, C. (2012) Globalization, Reflexivity and the Project of the Self: A Virtual Intercultural Learning Process. Consumption, Markets \& Culture. iFirst.

Kotler, P. (1972) What consumerism means for marketers. Harvard Business Review, 3, pp. 48-57.

Lambin, J.J. (1997) Strategic marketing management, Maidenhead: McGraw-Hill.

Menon, A. and Menon, A. (1997) Enviropreneurial Marketing Strategy: The Emergence of Corporate Environmentalism as Market Strategy. Journal of Marketing, 61(1), pp. 51-67.

Morgan, R.M. and Hunt, S.D. (1994) The Commitment-Trust Theory of Relationship Marketing. Journal of Marketing, 58 (3), pp. 20-38.

O'Shaughnessy, J. and O'Shaughnessy, N.J. (2002) Marketing, the Consumer Society and Hedonism. European Journal of Marketing, 36 (5/6), pp. 524-547.

Packard, V. (1957) The Hidden Persuaders. London: Longman.

Peñaloza, L. And Venkatesh, A. (2006) Further evolving the new dominant logic of marketing: From services to the social construction of market. Marketing Theory, 6 (3), pp. 299-316.

Palazzo, G. and Richter, U. (2005) CSR Business as Usual? The Case of the Tobacco Industry. Journal of Business Ethics. 61 (4), pp. 387-401.

Prothero, A. (1990) Green consumerism and the societal marketing concept Marketing strategies for the 1990s. Journal of Marketing Management, 6(2), pp. 87-103. 
Oliver, R.L. (1999) Whence Consumer Loyalty? Journal of Marketing, 63 (special issue), pp. 33-44.

Schor, J. B. (1999) The new politics of consumption. Boston Review, 24 (3/4), pp. 1 8.

Schwartz, M.S. and Carroll, A.B. (2003) Corporate Social Responsibility: A ThreeDomain Approach. Business Ethics Quarterly, 13(4), pp. 503-530.

Setterfield, M. (2005) Interactions in analytical political economy: theory, policy, and applications, New York: E.M. Sharpe Inc.

Shankar, V. and Malthouse, E.C. (2007) The growth of interactions and dialogs in interactive marketing. Journal of Interactive Marketing, 21(2), pp. 2-4.

Sheth, J.N., Sethia, N.K. and Srinivas, S. (2011) Mindful consumption: A customercentric approach to sustainability. Journal of the Academy of Marketing Science, 39(1), pp. 21-39.

Szmigin, I., Bengry-Howell, A., Griffin, C., Hackley, C. and Mistral, W. (2011) Social marketing, individual responsibility and the "culture of intoxication". European Journal of Marketing, 45(5), pp. 759-779.

Tadajewski, M. (2010) Towards a history of critical marketing studies. Journal of Marketing Management, 26 (9/10), pp. 773-824.

Takas, A. (1974) Societal Marketing: A Businessman's Perspective. Journal of Marketing, 38, 4, pp. 2-7.

Tan, S.J. (2002) Can consumers' scepticism be mitigated by claim objectivity and claim extremity? Journal of Marketing Communications, 8(1), pp. 45-64.

Varey, R.J. (2010) Marketing means and ends for a sustainable society: A welfare agenda for transformative change. Journal of Macromarketing, 30 (2), pp. 112126.

Venkatesh, A., Peñaloza, L. and Fırat, A.F. (2006) The Market as a Sign System and the Logic of the Market. In R.F. Lusch and S.L. Vargo (Eds.) The Service Dominant Logic of Marketing: Dialog, Debate and Direction, pp. 251-265. New York: M.E. Sharpe.

Wallis, J. (2010) Rediscovering Values: On Wall Street, Main Street, and Your Street: A Moral Compass for the New Economy. New York: Howard Books.

Wright, L.T., Newman, A., and Dennis, C. (2006) Enhancing Consumer Empowerment. European Journal of Marketing, 40(9/10), pp. 925-935.

Yani-De-Soriano, M. and Slater, S. (2009) Revisiting Drucker's theory: Has consumerism led to the overuse of marketing? Journal of Management History, 15 (4), pp. 452-466. 